\title{
The Inflammatory Role of Platelets: Translational Insights from Experimental Studies of Autoimmune Disorders
}

\author{
Susann Pankratz ${ }^{1, *}$, Stefan Bittner ${ }^{2}$, Beate E. Kehrel ${ }^{3}$, Harald F. Langer ${ }^{4,5}$, \\ Christoph Kleinschnitz ${ }^{6}$, Sven G. Meuth ${ }^{1,+}$ and Kerstin Göbel ${ }^{1, *,+}$ \\ 1 Department of Neurology, University of Münster, 48149 Münster, Germany; sven.meuth@ukmuenster.de \\ 2 Department of Neurology, University Medical Center of the Johannes Gutenberg-University, 55131 Mainz, \\ Germany; stefan.bittner@unimedizin-mainz.de \\ 3 Department of Anesthesiology, Intensive Care and Pain Medicine, Experimental and Clinical Hemostasis, \\ University of Münster, 48149 Münster, Germany; haemostasis.research@uni-muenster.de \\ 4 University Clinic for Cardiology and Cardiovascular Medicine, Eberhard Karls-University Tübingen, \\ 72076 Tübingen, Germany; Harald.Langer@med.uni-tuebingen.de \\ 5 Section for Cardioimmunology, Eberhard Karls-University Tübingen, 72076 Tübingen, Germany \\ 6 Department of Neurology, University Hospital Essen, 45147 Essen, Germany; \\ Christoph.Kleinschnitz@uk-essen.de \\ * Correspondence: susann.pankratz@ukmuenster.de (S.P.); kerstin.goebel@ukmuenster.de (K.G.); \\ Tel.: +49-251-83-44463 (S.P. \& K.G.); Fax: +49-251-83-46812 (S.P. \& K.G.) \\ + These authors contributed equally to this work.
}

Academic Editor: Cesar Borlongan

Received: 7 September 2016; Accepted: 8 October 2016; Published: 14 October 2016

\begin{abstract}
Beyond their indispensable role in hemostasis, platelets have shown to affect the development of inflammatory disorders, as they have been epidemiologically and mechanistically linked to diseases featuring an inflammatory reaction in inflammatory diseases like multiple sclerosis, rheumatoid arthritis and inflammatory bowel disorders. The identification of novel molecular mechanisms linking inflammation and to platelets has highlighted them as new targets for therapeutic interventions. In particular, genetic and pharmacological studies have identified an important role for platelets in neuroinflammation. This review summarizes the main molecular links between platelets and inflammation, focusing on immune regulatory factors, receptors, cellular targets and signaling pathways by which they can amplify inflammatory reactions and that make them potential therapeutic targets.
\end{abstract}

Keywords: platelets; autoimmunity; neuroinflammation

\section{Introduction}

Platelets are tiny anucleate cells that circulate in a quiescent discoid state in the blood stream [1]. Their well-known physiological function is to regulate hemostasis as cellular effectors of hemostasis. In this context, platelets are rapidly deployed to sites of vascular injury, where they are indispensable for orchestration to stop blood loss [2]. They adhere to exposed subendothelial matrix proteins of the damaged vessel wall such as collagen, von Willebrand factor (vWF) or collagen bound fibrinogen [3]. Through this firm interaction with the endothelium, platelets become locally activated and consequently change their shape from discoid to pseudopodia state. This activation includes the release of different mediators from their storage compartments into circulation, which, in turn, can activate and recruit additional platelets to the endothelial lesion [4]. Crosslinking of adjacent activated platelets along with the binding of fibrinogen to glycoprotein $(\mathrm{Gp}) \mathrm{Ilb} / \mathrm{III}$ (also known as 
integrin $\alpha_{\mathrm{IIb}} \beta_{3}$ or cluster of differentiation (CD) 41/CD61) on activated platelets results in platelet aggregation [5]. The forming primary platelet plug can limit bleeding and provides sealing of the endothelial wound. However, it has been shown that platelet activation is not just linked to beneficial effects in hemostasis. Dysregulation of the coagulation cascade can lead to an aberrant activation and, thus, aggregation of platelets that is mostly associated with cardiovascular pathogenesis (reviewed in detail elsewhere [6-9]). In addition to their well-understood and indispensable hemostatic role, platelets are receiving more and more interest as immune and inflammatory effector cells [10]. There is growing evidence that they actively participate in various immune-mediated pathogenic circumstances [11].

In this review, we summarize key links between platelets and inflammation, with a specific focus on molecular pathways in autoinflammatory disorders. The evidence presented here suggests that manipulation of platelets could be potentially therapeutically exploitable in autoimmune diseases in general.

\section{Platelets-Cellular Mediators of (Neuro-) Inflammation}

Given the fact that platelets are not only cellular effectors of hemostasis, but actively assist immune mediated (neuro-) inflammation, it is not surprising that platelets secret and shed a range of mediators both relevant for hemostasis and the immune response [12].

Platelets usually circulate in a quiescent state in the blood circulation, where they contact a variety of substances that activate them, including lipopolysaccharides (LPS) and toll-like receptor (TLR) ligands along with thrombin, collagen and adenosine diphosphate (ADP) [13,14]. Upon activation, platelets can directly and indirectly communicate with several target cells (e.g., leukocytes, endothelial cells) that are involved in the initiation and propagation of (neuro-) inflammatory reactions through various platelet-derived factors. These various factors can thus mediate activation, recruitment and transmigration of involved target cells. These platelet-derived factors can include the release of cytokines, chemokines and other mediators (like serotonin and ADP) from their main storage compartments ( $\alpha$ - and dense granules). Further, current studies indicate that platelet activation can also lead to de novo synthesis of mediators, like cytokines, by their regulated metabolic activity $[15,16]$. Beyond to their capacity to store and secrete immune modulatory molecules, activated platelets are highly effective at generating extracellular vesicles named microparticles (MP). Despite the fact that MP can be of various cellular origin (e.g., endothelial cells), platelet MP (PMP) represent the primary source of MP in the blood circulation [17]. The PMP content harbor an elaborate set of transcription factors, enzymes, micro ribonucleic acid and various mediators that can be delivered to surrounding target cells to impact their function [16]. Moreover, PMP, like platelets, expose a range of surface proteins which enable them both to provide binding sites for adjacent target cells (e.g., leukocytes, endothelial cells) and to deliver surrounded stimuli leading to the secretion of cytokines/chemokines, under the control of specific intracellular regulatory pathways. The main platelet receptors, which comprise TLR, siglecs, Gp as well as metabotropic purinergic receptors, and their ligands are reviewed in detail elsewhere $[14,18-20]$.

Increased amounts of platelet-derived factors along with increased activation status of platelets occur in the pathogenesis of several immune mediated inflammatory diseases.

\section{Role of Platelet-Driven Neuroinflammation in Multiple Sclerosis}

Multiple sclerosis (MS) is an inflammatory disease of the central nervous system (CNS), characterized by demyelination of neuronal axons. Although the aetiology and pathogenesis of MS are still not completely understood, it is widely accepted that MS is an immune-mediated disease [21]. It can be assumed that immunological processes during the initial phases of disease include the formation of self-reactive leukocytes in the peripheral circulation that eventually transmigrate across the activated blood-brain barrier (BBB). The subsequent disruption of the impermeable nature of the 
BBB facilitates the local recruitment of further inflammatory effector cells into the CNS parenchyma mediating tissue damage.

Emerging new concepts emphasize that factors that do not belong to the immune system are involved in inflammatory degeneration in MS. In particular, constituents of the plasmatic coagulation system and the contact systems have received interest [22,23]. Further, depositions of coagulation factors, such as fibrinogen or factor XII, were described in plaques of MS patients [23-25]. Besides the plasmatic coagulation, slight attention has also been given to platelets in the pathogenesis of MS in the past, despite the fact that early evidence from 1950s /60s pointed to platelet abnormalities in MS patients [26-29]. These data already suggested an immune mediated role for platelet contribution in MS, but were then largely forgotten in future generations of MS researchers. Indeed, current studies suggest that platelet depletion reduces disease severity and inflammation in mice that were subjected to experimental autoimmune encephalomyelitis (EAE), a classical animal model of CNS inflammation to study the pathogenesis of MS [30-32]. In particular, a number of studies have demonstrated that platelets are present along with an increased activation status in the peripheral blood and in plaques of MS patients as indicated by elevated PMP levels, P-selectin expression (also known as CD62P), increased levels of platelet-activating factor (PAF) and upregulation of GpIlb receptor (see Figure 1) [30,33-36]. Of note, the PMP level was higher in untreated MS patients and relapsing-remitting patients showed the highest levels both compared to respective controls, thus emphasizing a predictive role as biomarker [35]. Consistent with the findings in MS patients, an increased activation status of platelets has also found in inflamed CNS tissue of EAE mice [30,31,37], whereby EAE symptoms correlate with the levels of PAF [38]. Additionally, the genetic ablation of PAF receptor in EAE (see Table 1) led to decreased disease severity along with reduced CNS inflammation and demyelination [38]. Elevated platelet activation was linked to the interaction between platelets and CNS-specific cell compartments. Thereby, it was shown that platelets have the ability to recognize gangliosides (sialic acids) within the lipid rafts on the surface of astrocytes and neurons due to the disrupted integrity of the BBB. The relevance of platelet recognition of CNS-specific glycolipid structures is underscored by animal studies with reinforcement/inhibition and genetic ablation of platelet glycolipid interaction (see Tables 1 and 2). Platelet activation (expression of P-selectin) was triggered through this interaction following secretion of pro-inflammatory mediators, interleukin (IL)-1, platelet factor (PF)-4, and 5-hydroxytryptamine (5-HT or serotonin, see Figure 1) [31]. Interestingly, platelet-derived serotonin possesses the ability to recruit leukocytes (neutrophils) to the site of CNS inflammation [39]. Another experimental evidence revealed that 5-HT transporter knockout (5-HTT ${ }^{-/-}$, see Table 1) mice showed a decreased disease severity along with reduced CNS inflammation in EAE [40]. In line with this, treatment of relapsing MS patients with the antidepressant fluoxetine, which is a selective serotonin-reuptake inhibitor, reduced the disease activity due to its neuroprotective effect [41,42].

Full platelet activation can be induced in response to platelet-endothelial cell interactions. Note that, under physiological conditions, circulating platelets do not interact with intact endothelium. However, it is reported that platelets can also alter the phenotype of endothelial cells. In this context, it was demonstrated that platelets can indirectly contribute to the activation of cerebrovascular endothelium via released IL- $1 \alpha$. In addition, endothelial activation in response to platelet-derived IL- $1 \alpha$ was associated with the expression of cell adhesion molecules, intracellular adhesion molecule-1 (ICAM-1) and vascular cell adhesion protein (VCAM-1) as well as to enhanced release of CXC chemokine ligand 1 (CXCL1) [43]. Studies with human endothelial cells revealed similar results [44]. Besides IL-1, platelets can also modulate the BBB via their expression of CD40 Ligand (CD40L, also known as CD154). Like IL-1, CD40L enable platelets to indirectly interact with endothelium, which express CD40, thus triggering upregulation of adhesion molecules and chemokine [45]. The contribution of E- and P-selectin, additional adhesion molecules, in EAE pathogenesis were investigated (see Table 1), thus showing that they are not required for the development of EAE although P-selectin was found to be upregulated on both endothelium and platelets in inflamed 
CNS [37]. Nevertheless, the genetic ablation of platelet/endothelial cell adhesion molecule-1 (PECAM-1, also known as CD31) in animal studies of EAE (see Table 1) revealed that PECAM-1 plays a major role in the restoration of endothelial integrity [46].

As already mentioned, activation of platelets can be modulated by distinct receptors. In this context, the metabotropic purinergic ADP receptor $\mathrm{P}_{2} \mathrm{Y}_{12}$, which is mainly found on platelets, seems to play a significant role. Experimental inhibition of $\mathrm{P}_{2} \mathrm{Y}_{12}$ receptor by clopidogrel on human platelets showed a reduced release of both P-selectin and CD40 Ligand (CD40L) [47]. The relevance of $\mathrm{P}_{12} \mathrm{Y}_{12}$ receptor inhibitors like clopidogrel or prasugrel in MS patients has not yet been analyzed, but platelets can bind to CNS-specific lipid rafts through CD62P [31] and CD40L triggers endothelial activation [45], meaning both mediators fire neuroinflammatory processes. Furthermore, it was shown that dipyridamole decreased the clinical severity of EAE (see Table 2), although other molecular mechanisms than inhibition of platelet activation were relevant in this context [48]. Blockade of platelet key receptors (see Table 2) showed that platelets participate in EAE pathogenesis by recognizing integrins [30]. Here, it should be taken into account that Gp blocker might be an opportunity to treat MS. Copaxone, which are already successfully applied for MS therapy, seem to beneficially affect platelet activation additional to its known mode of action [49].

Although an increasing body of evidence clearly shows the inflammatory role of platelets and their derived factors/receptors in pathophysiology of MS and EAE, the role of platelets remain elusive so far. For instance, it is known that disease activity in MS undergoes shifts in the time before, during and after pregnancy with a clear reduction in relapse rates, especially in the last trimester, of $70 \%-80 \%$ [50]. Especially, in late pregnancy, it is known that increased platelet activation occurs and is associated with increased concentrations of $\beta$-thromboglobulin and thromboxane A2 [51,52]. However, whether these findings hold also true in MS patients has not been examined so far, so further studies are required.

Table 1. Studies of platelets, their receptors and molecules: effects on inflammatory processes of the central nervous system in transgenic mice.

\begin{tabular}{|c|c|c|c|}
\hline $\begin{array}{c}\text { Mouse Line } \\
\text { (Genetic Background) }\end{array}$ & Model (Peptide) & Inflammatory Effect & Referene \\
\hline $\begin{array}{l}\text { ST3Gal- } V^{-/-} \\
(\mathrm{C} 57 \mathrm{BL} / 6)\end{array}$ & EAE $\left(\mathrm{MOG}_{35-55}\right)$ & $\begin{array}{l}\text { Ameliorated disease course due to lack of brain-specific } \\
\text { gangliosides that can recognize by platelets. Reduced CNS } \\
\text { inflammation as determined by the infiltration of less lymphocytes, } \\
\text { CD4 T cells and macrophages on day } 21 \text { after the EAE induction. }\end{array}$ & [31] \\
\hline $\begin{array}{l}\text { E-/P-selectin }-/- \\
\quad(\mathrm{C} 57 \mathrm{BL} / 6)\end{array}$ & $\operatorname{EAE}\left(\mathrm{MOG}_{35-55}\right)$ & No effect on clinical symptoms. & [37] \\
\hline $\begin{array}{l}5-H T T^{-/-} \\
(\mathrm{C} 57 \mathrm{BL} / 6)\end{array}$ & $\operatorname{EAE}\left(\mathrm{MOG}_{35-55}\right)$ & Decreased disease severity. Reduced CNS inflammation. & [40] \\
\hline $\begin{array}{l}5-H T T^{-/-} \\
(\mathrm{C} 57 \mathrm{BL} / 6)\end{array}$ & EAE (rat MBP) & Decreased disease severity. & [40] \\
\hline $\begin{array}{l}\text { PECAM-1-/- } \\
(\mathrm{C} 57 \mathrm{BL} / 6)\end{array}$ & EAE $\left(\mathrm{MOG}_{35-55}\right)$ & $\begin{array}{l}\text { Early onset of clinical symptoms associated with early leukocyte } \\
\text { migration into CNS. }\end{array}$ & [46] \\
\hline $\begin{array}{l}\text { PECAM-1-/- } \\
(\mathrm{C} 57 \mathrm{BL} / 6)\end{array}$ & $\begin{array}{l}\text { Adoptive transfer of } \\
\text { EAE }\left(\mathrm{MOG}_{35-55}\right)\end{array}$ & $\begin{array}{l}\text { Early onset of clinical symptoms regardless of whether KO mice } \\
\text { were injected with } \mathrm{MOG}_{35-55^{-}} \text {-specific WT or PECAM-1-/- T cells. }\end{array}$ & [46] \\
\hline
\end{tabular}

Abbreviations: CD, cluster of differentiation; CNS, central nervous systems; EAE, experimental autoimmune encephalomyelitis; FCR $\gamma$-chain, Fc receptor $\gamma$-chain; Gp, glycoprotein; 5-HTT, 5-hydroxytryptamine (common name serotonin) transporter; IL, interleukin; KO, knockout; MBP, myelin basic protein; MOG $_{35-55}$, myelin oligodendrocyte glycoprotein 35-55; PAF, platelet-activating factor; PECAM-1, platelet/endothelial cell adhesion molecule-1 (also known as CD31); PLP $_{139-151}$, proteolipid protein 139-151; WT, wild type. 
Table 2. Studies of platelets, their receptors and molecules contributing to neurovascular inflammation using pharmacological substances/experimental manipulations.

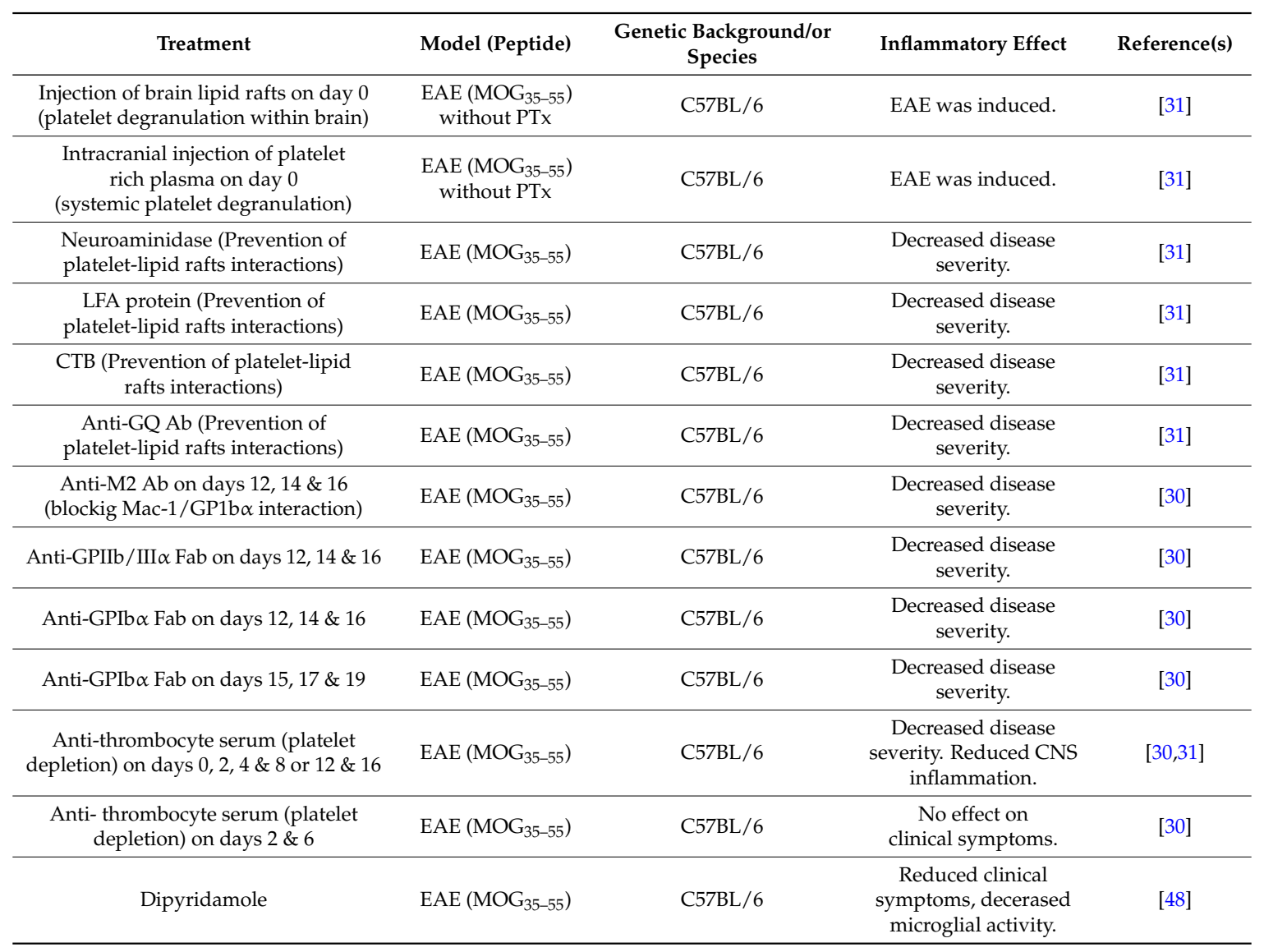

Abbreviations: $\mathrm{Ab}$, antibody; $\mathrm{CD}$, cluster of differentiation; CNS, central nervous systems; $\mathrm{CTB}, \beta$ subunit of cholera toxin; EAE, experimental autoimmune encephalomyelitis; Fab, Fragment antigen binding; FcR $\gamma$-chain, Fc receptor $\gamma$-chain; Gp, glycoprotein; LFA, Limax flavus agglutinin; MOG $_{35-55}$, myelin oligodendrocyte glycoprotein 35-55; PECAM-1, platelet/endothelial cell adhesion molecule-1 (also known as CD31); PF4, platelet factor 4 (also known as CXCL4); PLP 139-151, proteolipid protein 139-151; PTx, Pertussis toxin; WT, wildtype.

\section{Role of Platelet-Driven Immune Responses in Other Non-Neurological Inflammatory Disorders}

An increasing body of evidence also supports the role of platelets and platelet-derived factors in non-neurological auto-inflammatory diseases. In the following, we focus on two well-characterized disorders (rheumatoid arthritis (RA) and inflammatory bowel disorders (IBD)) to elaborate the immunological role of platelets.

\section{Rheumatoid Arthritis}

In particular, a substantial contribution of platelet-derived factors has been suggested in rheumatoid arthritis (RA; reviewed in detail elsewhere [53]) as platelet glycoprotein IIb/IIIa can be detected in the synovium of patients with RA [54,55]. Moreover, the activation marker P-selectin is higher in platelets from patients with active RA than those in remission [56] and elevated levels of PMP and soluble CD40L as well as P-selectin are reported in individuals suffering from RA [57-63]. Further, platelet aggregates and platelet or PMP adherent to leukocytes have been detected in both blood and synovial fluids of RA patients [58,64-70]. In vitro, it was shown that platelets are hyper-responsive to further activation, potentially reflecting the in vivo priming of platelets during disease [71,72].

A further direct pro-inflammatory role of platelets was suggested as its depletion in mice leads to an improvement in the clinical symptoms in an animal model of RA and results in decreased 
inflammation, bone and cartilage erosion (see Table 3) [70]. Interestingly, it was shown that GPVI is the relevant receptor for this effect, while neither thromboxane production or blockade of its receptor nor GPIb $\alpha$ was necessary in this context (see Tables 3 and 4) [70]. Furthermore, it was shown that genetic depletion of COX-1 in mice resulted in an ameliorated disease course in an animal model of RA [53]. Even more surprising, treatment with $\mathrm{P}_{2} \mathrm{Y}_{12}$ receptor antagonists like prasugrel leads to an aggravated disease course [70,73]; however, to support the potential human relevance, several case reports of patients developing spontaneous joint inflammation after clopidogrel intake exist [74-79]. Additionally, the effect of dipyridamole was tested as a therapy in RA patients, but it did not modify disease severity [80].

Table 3. Studies of platelets and platelet-derived factors: effects on inflammatory processes in transgenic mice.

\begin{tabular}{|c|c|c|c|}
\hline $\begin{array}{c}\text { Mouse Line } \\
\text { (Genetic Background) }\end{array}$ & Model (Peptide) & Inflammatory Effect & Reference \\
\hline $\operatorname{Cox} 1^{-1-}$ & $\begin{array}{l}\mathrm{K} / \mathrm{BxN} \text { serum transfer } \\
\text { arthritis }(\mathrm{K} / \mathrm{BxN} \text { serum })\end{array}$ & Ameliorated disease course due to platelet-derived COX-1 & [53] \\
\hline Gp1ba $a^{-/-}(\mathrm{C} 57 \mathrm{BL} / 6)$ & $\begin{array}{l}\mathrm{K} / \mathrm{BxN} \text { serum transfer } \\
\text { arthritis }(\mathrm{K} / \mathrm{BxN} \text { serum })\end{array}$ & No clinical effect & [70] \\
\hline $\mathrm{Gp6}^{-/-}(\mathrm{C} 57 \mathrm{BL} / 6)$ & $\begin{array}{l}\mathrm{K} / \mathrm{BxN} \text { serum transfer } \\
\text { arthritis }(\mathrm{K} / \mathrm{BxN} \text { serum })\end{array}$ & $\begin{array}{l}\text { Decreased disease severity. Reduced inflammation, } \\
\text { bone erosion, cartilage erosion }\end{array}$ & {$[70]$} \\
\hline Tbxas1 ${ }^{-/-}(\mathrm{C} 57 \mathrm{BL} / 6)$ & $\begin{array}{l}\mathrm{K} / \mathrm{BxN} \text { serum transfer } \\
\text { arthritis }(\mathrm{K} / \mathrm{BxN} \text { serum })\end{array}$ & No effect on clinical symptoms & [70] \\
\hline$C D 40^{-/-}(\mathrm{C} 57 \mathrm{BL} / 6)$ & Colitis (DSS) & $\begin{array}{l}\text { Attenuated disease activity, reduced inflammation and MPO } \\
\text { activity, reduced platelet and leukocyte adhesion }\end{array}$ & [81] \\
\hline $\mathrm{CD}_{40 L^{-/-}}(\mathrm{C} 57 \mathrm{BL} / 6)$ & Colitis (DSS) & $\begin{array}{l}\text { Attenuated disease activity, reduced inflammation and MPO } \\
\text { activity, reduced platelet and leukocyte adhesion }\end{array}$ & [81] \\
\hline \multirow[t]{3}{*}{ P-Selectin ${ }^{-/-}(\mathrm{C} 57 \mathrm{BL} / 6)$} & Colitis (DSS) & Reduced platelet adhesion and rolling & [81] \\
\hline & & Reduced platelet adhesion, decreased albumin extravasation & [82] \\
\hline & & $\begin{array}{l}\text { Enhanced disease activity, reduced MPO activity, } \\
\text { inflammation, leukocyte rolling }\end{array}$ & [83] \\
\hline \multirow[t]{3}{*}{ PSGL-1-1- (C57BL/6) } & Colitis (DSS) & Reduced platelet adhesion and rolling & [81] \\
\hline & & $\begin{array}{l}\text { Earlier disease onset, enhanced disease activity, enhanced } \\
\text { infiltration, platelets not examined }\end{array}$ & [84] \\
\hline & & $\begin{array}{l}\text { Decreased disease activity, inflammation, reduced Th1 and } \\
\text { Th17 infiltration, platelets not examined }\end{array}$ & [85] \\
\hline PSGL-1 ${ }^{-/-}($Balb/c) & Colitis (DSS) & $\begin{array}{l}\text { Reduced clinical disease activity, decreased leukocyte rolling, } \\
\text { inflammation and MPO activity, platelets not examined }\end{array}$ & [86] \\
\hline
\end{tabular}

Abbreviations: Cox1, cyclooxygenase-1; DSS, dextran sulfate sodium ; Gp, glycoprotein; K/BxN, KRN and MHC class II molecule I-A (g7); MPO, myeloperoxidase; Tbxas1, Thromboxane A synthase 1.

Thus, platelet activation mechanisms engaged during RA seems to be different from the typical pathways involved in thrombosis, so that not all drugs currently used to inhibit platelet function might have a protective effect in the context of arthritis.

\section{Inflammatory Bowel Disease}

In addition to RA, potential contribution of platelets and platelet-derived factors is also under consideration for inflammatory bowel disease (IBD), namely Crohn's disease and ulcerative colitis (reviewed in detail elsewhere $[87,88]$ ). These disorders are known to be associated with an increased risk for thromboembolism [87]. Interestingly, there is evidence that patients suffering from IBD reveal a larger number but smaller size of platelets. This finding is proposed to be used as a marker for disease activity [89-93]. Furthermore, it was shown that both expression of P-selectin, GP53 and CD40L on circulating platelets, appearance of platelet-leukocyte aggregates and soluble CD40L, $\beta$-thromboglobulin and PF-4 are increased in IBD patients [94-97]. In line with these findings, animal models of colitis have demonstrated accumulation of platelets in colonic venules that correlated with disease activity and adherent leukocytes and were predominantly attached to the surface of 
leukocytes [81,82]. In this model, pharmacological depletion of platelets induces reduced rolling and adhesion of leukocytes [81]. Genetic depletion or pharmacological blockade of both P-selectin of PSGL-1 led to reduced platelet and leukocyte adhesion in mice, while findings concerning disease activity revealed contradictory results (see Tables 3 and 4) [81-86]. Furthermore, the same group could show that genetic depletion of CD40 or its ligand is protective in animal model of colitis with reduced platelet and leukocyte adhesion (see Table 3). Nonetheless, blockade of GPIIb/IIIa had no effect on platelet adhesion in an experimental model of colitis [82]. In contrast to RA, pharmacological blockade of $\mathrm{P}_{2} \mathrm{Y}_{12}$ receptor by clopidogrel or treatment with acetylsalicylic acid reveals an attenuated disease course in models of IBD $[98,99]$.

Collectively, these results demonstrate a clear role of platelets and platelet-derived factors, not only in neuroinflammation, but also in other autoimmune disorders.

Table 4. Studies of platelets and platelet-derived factors: effects on inflammatory processes using pharmacological substances.

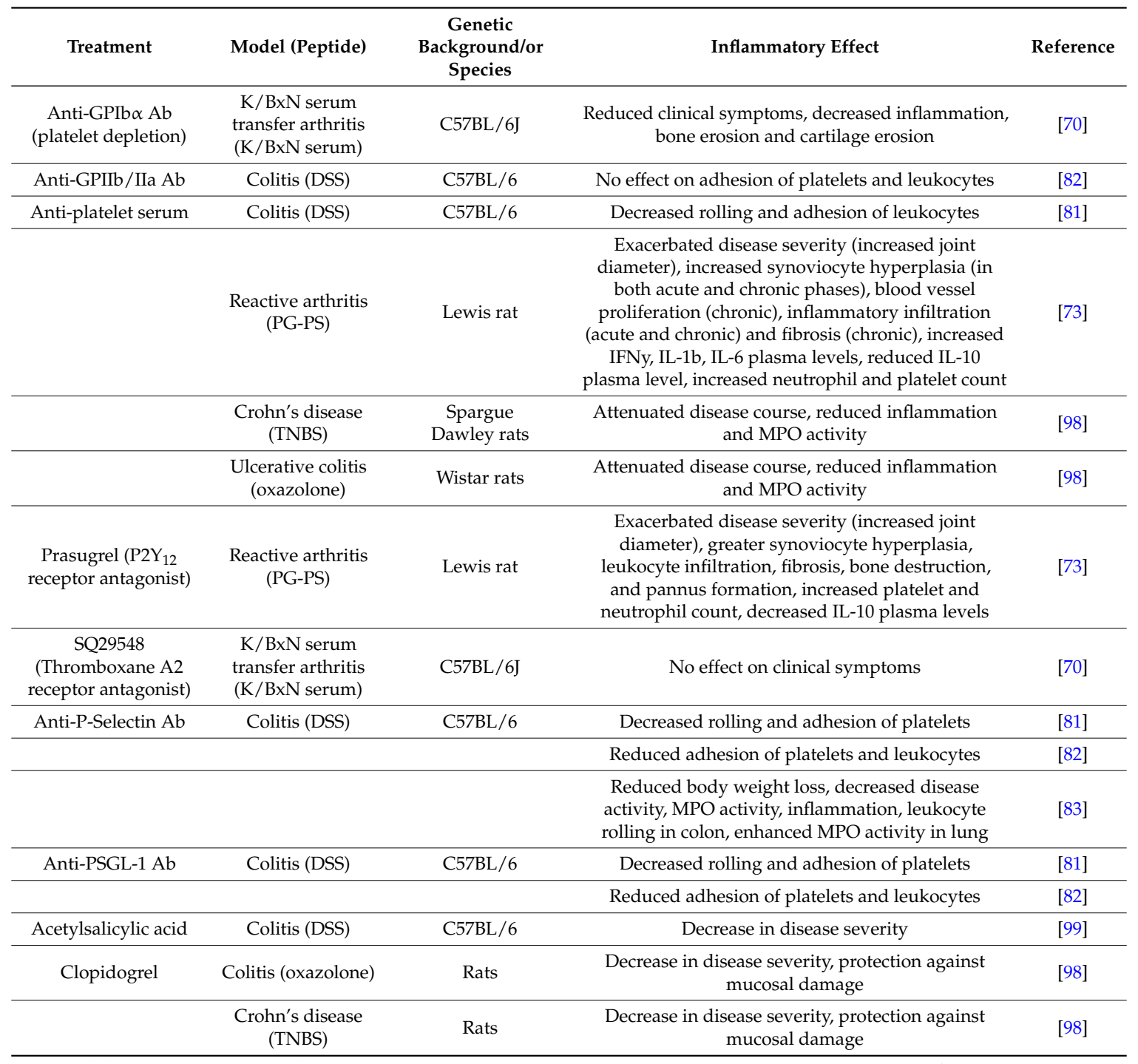

Abbreviations: $\mathrm{Ab}$, antibody; AIA, antigen-induced arthritis; Gp, glycoprotein; IFNy, Interferon gamma; IL, Interleukin; K/BxN, KRN and MHC class II molecule I-A (g7); PG-PS, Peptidoglycan polysaccharide; TNBS, Trinitrobenzenesulphonic acid. 


\section{Future Prospects/Concluding Remarks}

Beyond their hemostatic functions, platelets have the capacity to produce and secrete a variety of immune modulatory mediators after activation in response to various factors leading to initiation and modulation of immune-mediated inflammatory processes via interaction with other platelets, leukocytes and the endothelium. In this context, increased amounts of platelet-derived factors along with an increased activation status of platelets occur in the pathogenesis of MS, RA and IBD, emphasizing that modulating platelet activity may be beneficial. Furthermore, platelets and platelet-associated molecules have been tested as targets for imaging tools in vascular inflammation [100]. Thereby, platelets and their activation status merit consideration as a tool and biomarker in immune-mediated disease prediction [35] and also as targets for therapy of (neuro-)inflammation [49,101]. A recent report has implicated platelets as effectors of tissue remodeling processes such as apoptosis after brain damage using a model of transient ischemia [102]. This unexpected role of platelets within the neuronal tissue will have to be further questioned in additional experimental settings. In conclusion, further research is still required to elucidate the underlying mechanism(s) by which platelets, their receptors and platelet-derived factors modulate vascular integrity, and leukocyte crosstalk will aid in our understanding of the role platelets might play during inflammatory immune responses. Some of these targets already have available drugs, which creates an opportunity to merely repurpose them for use in immune mediated disease, like MS.

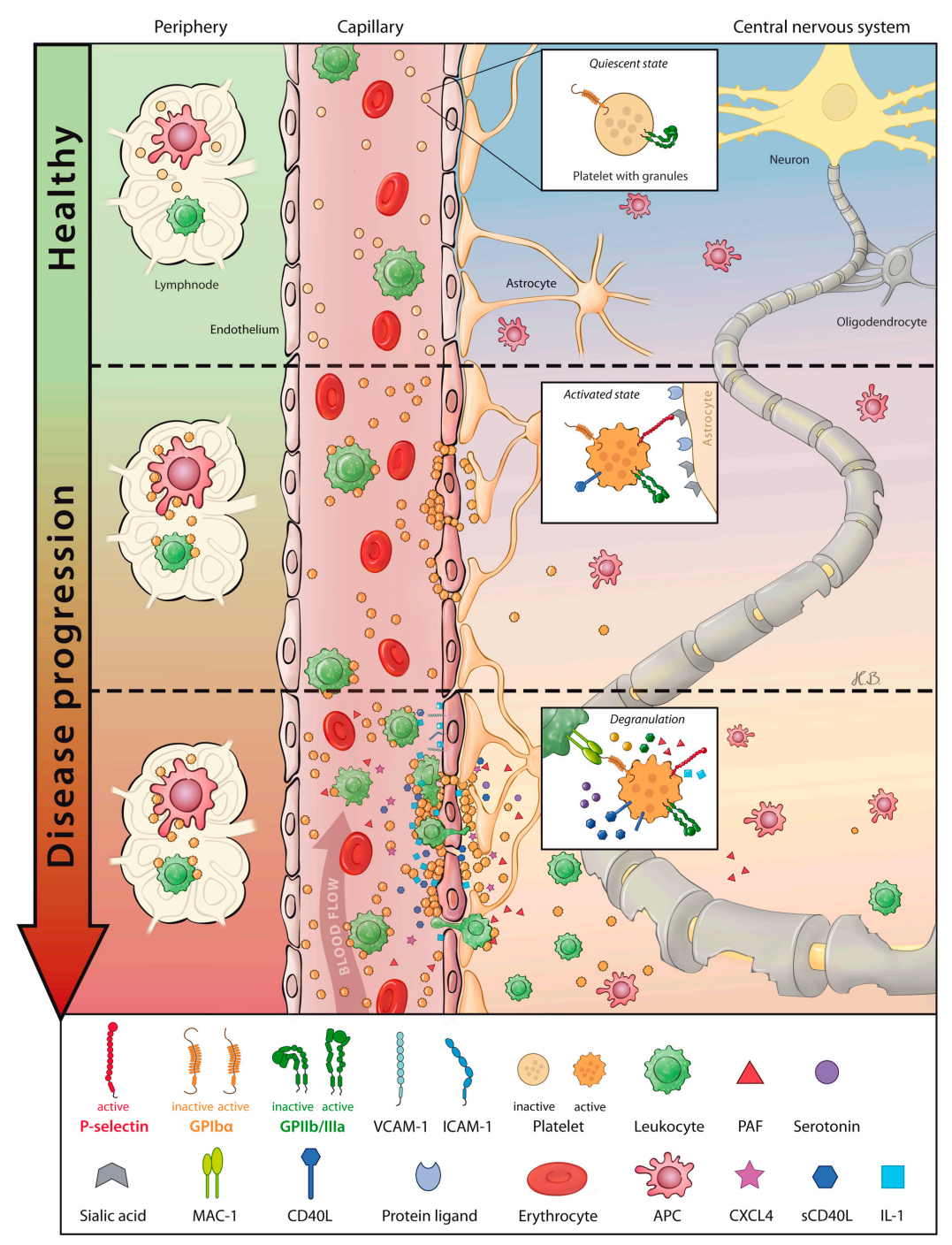

Figure 1. Platelet participation in pathophysiology of multiple sclerosis. 
Under steady state, platelets circulate in a quiescent state in the blood peripheral blood stream. Disruption of the impermeable nature of the BBB is a pathophysiological hallmark of MS and its animal model, EAE. Platelets rapidly deployed to sites of neurovascular injury to restore endothelial integrity and interact with lipid rafts within CNS parenchyma. This initial interaction is possible since platelets recognize sialic acids within the lipid rafts, which results in the expose of P-selectin on platelet surface. Upon activation, platelets active secret chemokines/cytokines and upregulate surface molecules, which both enable them to more efficiently communicate with target cells. Thereby, platelets mediate leukocyte recruitment and activation of endothelial cells. Leukocytes adhere to activated endothelium through adhesion molecules that promote leukocyte-endothelial interaction and leukocyte transmigration. Thus, platelets facilitate immune cell infiltration from the periphery into the CNS, where they may become reactivated and fan the fire of neuroinflammation.

Acknowledgments: The authors are grateful to Heike Blum for excellent work on the graphical illustration. This work was supported by the Innovative Medical Research (IMF) Münster (GÖ 111401 to Kerstin Göbel), the Else-Kröner-Fresenius-Stiftung (EKFS) (2015_A113 to Kerstin Göbel), the Deutsche Forschungsgemeinschaft (DFG) (GO2505/1-1 to Kerstin Göbel, KFO 274 to Harald F. Langer, ME3283/5-1 to Sven G. Meuth, BI1822/1-1 to Stefan Bittner), the Volkswagenfoundation (Lichtenberg program to Harald F. Langer), excellence cluster "Cells in Motion" in Münster; research group FOR2289 (ME 3283/6-1 to Sven G. Meuth) and the Medical Faculty (Junior Research Group to Kerstin Göbel).

Author Contributions: All authors approved the final manuscript and had input in revising it for intellectual content and style.

Conflicts of Interest: The authors declare no conflict of interest.

\section{Abbreviations}

APC, antigen presenting cells; CD40L, cluster of differentiation 40 ligand; CXCL1, CXC-chemokine ligand 1; Gp, glycoprotein; ICAM-1, intracellular adhesion molecule-1; IL-1 $\alpha$, interleukin- $1 \alpha$; MAC-1; macrophage-1 antigen (also known as integrin $\alpha \mathrm{M} \beta 2$ ); sCD40L, soluble CD40 ligand; VCAM-1, Vascular cell adhesion protein 1.

\section{References}

1. Ghoshal, K.; Bhattacharyya, M. Overview of platelet physiology: Its hemostatic and nonhemostatic role in disease pathogenesis. Sci. World J. 2014, 2014, 781857. [CrossRef] [PubMed]

2. Langer, H.F.; Gawaz, M. Platelet-vessel wall interactions in atherosclerotic disease. Thromb. Haemost. 2008, 99, 480-486. [CrossRef] [PubMed]

3. Yun, S.H.; Sim, E.H.; Goh, R.Y.; Park, J.I.; Han, J.Y. Platelet Activation: The Mechanisms and Potential Biomarkers. BioMed Res. Int. 2016, 2016, 9060143. [CrossRef] [PubMed]

4. Thomas, M.R.; Storey, R.F. The role of platelets in inflammation. Thromb. Haemost. 2015, 114, 449-458. [CrossRef] [PubMed]

5. Budnik, I.; Shenkman, B.; Savion, N. Synergistic effect of signaling from receptors of soluble platelet agonists and outside-in signaling in formation of a stable fibrinogen-integrin $\alpha \mathrm{IIb} \beta 3$-actin cytoskeleton complex. Thromb. Res. 2015, 135, 114-120. [CrossRef] [PubMed]

6. Jackson, S.P. Arterial thrombosis-Insidious, unpredictable and deadly. Nat. Med. 2011, 17, $1423-1436$. [CrossRef] [PubMed]

7. Van Rooy, M.J.; Pretorius, E. Metabolic syndrome, platelet activation and the development of transient ischemic attack or thromboembolic stroke. Thromb. Res. 2015, 135, 434-442. [CrossRef] [PubMed]

8. Patzelt, J.; Verschoor, A.; Langer, H.F. Platelets and the complement cascade in atherosclerosis. Front. Physiol. 2015, 6, 49. [CrossRef] [PubMed]

9. Nording, H.M.; Seizer, P.; Langer, H.F. Platelets in inflammation and atherogenesis. Front. Physiol. 2015, 6, 98. [CrossRef] [PubMed]

10. Langer, H.F.; Chavakis, T. Leukocyte-endothelial interactions in inflammation. J. Cell. Mol. Med. 2009, 13, 1211-1220. [CrossRef] [PubMed]

11. Herter, J.M.; Rossaint, J.; Zarbock, A. Platelets in inflammation and immunity. J. Thromb. Haemost. 2014, 12, 1764-1775. [CrossRef] [PubMed] 
12. Gawaz, M.; Langer, H.; May, A.E. Platelets in inflammation and atherogenesis. J. Clin. Investig. 2005, 115, 3378-3384. [CrossRef] [PubMed]

13. Rondina, M.T.; Garraud, O. Emerging evidence for platelets as immune and inflammatory effector cells. Front. Immunol. 2014, 5, 653. [CrossRef] [PubMed]

14. Horstman, L.L.; Jy, W.; Ahn, Y.S.; Zivadinov, R.; Maghzi, A.H.; Etemadifar, M.; Alexander, J.S.; Minagar, A. Role of platelets in neuroinflammation: A wide-angle perspective. J. Neuroinflamm. 2010, 7, 10. [CrossRef] [PubMed]

15. Lindemann, S.; Tolley, N.D.; Dixon, D.A.; McIntyre, T.M.; Prescott, S.M.; Zimmerman, G.A.; Weyrich, A.S. Activated platelets mediate inflammatory signaling by regulated interleukin $1 \beta$ synthesis. J. Cell Biol. 2001, 154, 485-490. [CrossRef] [PubMed]

16. Lannan, K.L.; Sahler, J.; Kim, N.; Spinelli, S.L.; Maggirwar, S.B.; Garraud, O.; Cognasse, F.; Blumberg, N.; Phipps, R.P. Breaking the mold: Transcription factors in the anucleate platelet and platelet-derived microparticles. Front. Immunol. 2015, 6, 48. [CrossRef] [PubMed]

17. Horstman, L.L.; Ahn, Y.S. Platelet microparticles: A wide-angle perspective. Crit. Rev. Oncol. Hematol. 1999, 30, 111-142. [CrossRef]

18. Cognasse, F.; Nguyen, K.A.; Damien, P.; McNicol, A.; Pozzetto, B.; Hamzeh-Cognasse, H.; Garraud, O. The Inflammatory Role of Platelets via Their TLRs and Siglec Receptors. Front. Immunol. 2015, 6, 83. [CrossRef] [PubMed]

19. Oury, C.; Lecut, C.; Hego, A.; Wera, O.; Delierneux, C. Purinergic control of inflammation and thrombosis: Role of P2X1 receptors. Comput. Struct. Biotechnol. J. 2015, 13, 106-110. [CrossRef] [PubMed]

20. Mezger, M.; Gobel, K.; Kraft, P.; Meuth, S.G.; Kleinschnitz, C.; Langer, H.F. Platelets and vascular inflammation of the brain. Hamostaseologie 2015, 35, 244-251. [CrossRef] [PubMed]

21. Bhat, R.; Steinman, L. Innate and adaptive autoimmunity directed to the central nervous system. Neuron 2009, 64, 123-132. [CrossRef] [PubMed]

22. Gobel, K.; Pankratz, S.; Schneider-Hohendorf, T.; Bittner, S.; Schuhmann, M.K.; Langer, H.F.; Stoll, G.; Wiendl, H.; Kleinschnitz, C.; Meuth, S.G. Blockade of the kinin receptor B1 protects from autoimmune CNS disease by reducing leukocyte trafficking. J. Autoimmun. 2011, 36, 106-114. [CrossRef] [PubMed]

23. Gobel, K.; Pankratz, S.; Asaridou, C.M.; Herrmann, A.M.; Bittner, S.; Merker, M.; Ruck, T.; Glumm, S.; Langhauser, F.; Kraft, P.; et al. Blood coagulation factor XII drives adaptive immunity during neuroinflammation via CD87-mediated modulation of dendritic cells. Nat. Commun. 2016, 7, 11626. [CrossRef] [PubMed]

24. Davalos, D.; Akassoglou, K. Fibrinogen as a key regulator of inflammation in disease. Semin. Immunopathol. 2012, 34, 43-62. [CrossRef] [PubMed]

25. Adams, R.A.; Bauer, J.; Flick, M.J.; Sikorski, S.L.; Nuriel, T.; Lassmann, H.; Degen, J.L.; Akassoglou, K. The fibrin-derived $\gamma 377-395$ peptide inhibits microglia activation and suppresses relapsing paralysis in central nervous system autoimmune disease. J. Exp. Med. 2007, 204, 571-582. [CrossRef] [PubMed]

26. Nathanson, M.; Savitsky, J.P. Platelet adhesive index studies in multiple sclerosis and other neurologic disorders. Bull. N. Y. Acad. Med. 1952, 28, 462-468. [PubMed]

27. Millar, J.H.; Merrett, J.D.; Dalby, A.M. Platelet stickiness in multiple sclerosis. J. Neurol. Neurosurg. Psychiatry 1966, 29, 187-189. [CrossRef] [PubMed]

28. Bolton, C.H.; Hampton, J.R.; Phillipson, O.T. Platelet behaviour and plasma phospholipids in multiple sclerosis. Lancet 1968, 1, 99-104. [CrossRef]

29. Andreoli, V.M.; Cazzullo, C.L. Platelet behaviour in multiple sclerosis. Lancet 1968, 1, 528-529. [CrossRef]

30. Langer, H.F.; Choi, E.Y.; Zhou, H.; Schleicher, R.; Chung, K.J.; Tang, Z.; Gobel, K.; Bdeir, K.; Chatzigeorgiou, A.; Wong, C.; et al. Platelets contribute to the pathogenesis of experimental autoimmune encephalomyelitis. Circ. Res. 2012, 110, 1202-1210. [CrossRef] [PubMed]

31. Sotnikov, I.; Veremeyko, T.; Starossom, S.C.; Barteneva, N.; Weiner, H.L.; Ponomarev, E.D. Platelets recognize brain-specific glycolipid structures, respond to neurovascular damage and promote neuroinflammation. PLoS ONE 2013, 8, e58979. [CrossRef] [PubMed]

32. Starossom, S.C.; Veremeyko, T.; Yung, A.W.; Dukhinova, M.; Au, C.; Lau, A.Y.; Weiner, H.L.; Ponomarev, E.D. Platelets Play Differential Role During the Initiation and Progression of Autoimmune Neuroinflammation. Circ. Res. 2015, 117, 779-792. [CrossRef] [PubMed] 
33. Callea, L.; Arese, M.; Orlandini, A.; Bargnani, C.; Priori, A.; Bussolino, F. Platelet activating factor is elevated in cerebral spinal fluid and plasma of patients with relapsing-remitting multiple sclerosis. J. Neuroimmunol. 1999, 94, 212-221. [CrossRef]

34. Sheremata, W.A.; Jy, W.; Horstman, L.L.; Ahn, Y.S.; Alexander, J.S.; Minagar, A. Evidence of platelet activation in multiple sclerosis. J. Neuroinflamm. 2008, 5, 27. [CrossRef] [PubMed]

35. Saenz-Cuesta, M.; Irizar, H.; Castillo-Trivino, T.; Munoz-Culla, M.; Osorio-Querejeta, I.; Prada, A.; Sepulveda, L.; Lopez-Mato, M.P.; de Munain, A.L.; Comabella, M.; et al. Circulating microparticles reflect treatment effects and clinical status in multiple sclerosis. Biomark. Med. 2014, 8, 653-661. [CrossRef] [PubMed]

36. Lock, C.; Hermans, G.; Pedotti, R.; Brendolan, A.; Schadt, E.; Garren, H.; Langer-Gould, A.; Strober, S.; Cannella, B.; Allard, J.; et al. Gene-microarray analysis of multiple sclerosis lesions yields new targets validated in autoimmune encephalomyelitis. Nat. Med. 2002, 8, 500-508. [CrossRef] [PubMed]

37. Doring, A.; Wild, M.; Vestweber, D.; Deutsch, U.; Engelhardt, B. E- and P-selectin are not required for the development of experimental autoimmune encephalomyelitis in C57BL/6 and SJL mice. J. Immunol. 2007, 179, 8470-8479. [CrossRef] [PubMed]

38. Kihara, Y.; Ishii, S.; Kita, Y.; Toda, A.; Shimada, A.; Shimizu, T. Dual phase regulation of experimental allergic encephalomyelitis by platelet-activating factor. J. Exp. Med. 2005, 202, 853-863. [CrossRef] [PubMed]

39. Duerschmied, D.; Suidan, G.L.; Demers, M.; Herr, N.; Carbo, C.; Brill, A.; Cifuni, S.M.; Mauler, M.; Cicko, S.; Bader, M.; et al. Platelet serotonin promotes the recruitment of neutrophils to sites of acute inflammation in mice. Blood 2013, 121, 1008-1015. [CrossRef] [PubMed]

40. Hofstetter, H.H.; Mossner, R.; Lesch, K.P.; Linker, R.A.; Toyka, K.V.; Gold, R. Absence of reuptake of serotonin influences susceptibility to clinical autoimmune disease and neuroantigen-specific interferon-gamma production in mouse EAE. Clin. Exp. Immunol. 2005, 142, 39-44. [CrossRef] [PubMed]

41. Mostert, J.P.; Admiraal-Behloul, F.; Hoogduin, J.M.; Luyendijk, J.; Heersema, D.J.; van Buchem, M.A.; de Keyser, J. Effects of fluoxetine on disease activity in relapsing multiple sclerosis: A double-blind, placebo-controlled, exploratory study. J. Neurol. Neurosurg. Psychiatry 2008, 79, 1027-1031. [CrossRef] [PubMed]

42. Sijens, P.E.; Mostert, J.P.; Irwan, R.; Potze, J.H.; Oudkerk, M.; de Keyser, J. Impact of fluoxetine on the human brain in multiple sclerosis as quantified by proton magnetic resonance spectroscopy and diffusion tensor imaging. Psychiatry Res. 2008, 164, 274-282. [CrossRef] [PubMed]

43. Thornton, P.; McColl, B.W.; Greenhalgh, A.; Denes, A.; Allan, S.M.; Rothwell, N.J. Platelet interleukin- $1 \alpha$ drives cerebrovascular inflammation. Blood 2010, 115, 3632-3639. [CrossRef] [PubMed]

44. Hawrylowicz, C.M.; Howells, G.L.; Feldmann, M. Platelet-derived interleukin 1 induces human endothelial adhesion molecule expression and cytokine production. J. Exp. Med. 1991, 174, 785-790. [CrossRef] [PubMed]

45. Henn, V.; Slupsky, J.R.; Grafe, M.; Anagnostopoulos, I.; Forster, R.; Muller-Berghaus, G.; Kroczek, R.A. CD40 ligand on activated platelets triggers an inflammatory reaction of endothelial cells. Nature 1998, 391, 591-594. [PubMed]

46. Graesser, D.; Solowiej, A.; Bruckner, M.; Osterweil, E.; Juedes, A.; Davis, S.; Ruddle, N.H.; Engelhardt, B.; Madri, J.A. Altered vascular permeability and early onset of experimental autoimmune encephalomyelitis in PECAM-1-deficient mice. J. Clin. Investig. 2002, 109, 383-392. [CrossRef] [PubMed]

47. Hermann, A.; Rauch, B.H.; Braun, M.; Schror, K.; Weber, A.A. Platelet CD40 ligand (CD40L)—Subcellular localization, regulation of expression, and inhibition by clopidogrel. Platelets 2001, 12, 74-82. [CrossRef] [PubMed]

48. Sloka, S.; Metz, L.M.; Hader, W.; Starreveld, Y.; Yong, V.W. Reduction of microglial activity in a model of multiple sclerosis by dipyridamole. J. Neuroinflamm. 2013, 10, 89. [CrossRef] [PubMed]

49. Starossom, S.C.; Veremeyko, T.; Dukhinova, M.; Yung, A.W.; Ponomarev, E.D. Glatiramer acetate (copaxone) modulates platelet activation and inhibits thrombin-induced calcium influx: Possible role of copaxone in targeting platelets during autoimmune neuroinflammation. PLoS ONE 2014, 9, e96256. [CrossRef] [PubMed]

50. Gold, S.M.; Voskuhl, R.R. Pregnancy and multiple sclerosis: From molecular mechanisms to clinical application. Semin. Immunopathol. 2016. [CrossRef] [PubMed]

51. Douglas, J.T.; Shah, M.; Lowe, G.D.; Belch, J.J.; Forbes, C.D.; Prentice, C.R. Plasma fibrinopeptide A and $\beta$-thromboglobulin in pre-eclampsia and pregnancy hypertension. Thromb. Haemost. 1982, 47, 54-55. [PubMed] 
52. Fitzgerald, D.J.; Mayo, G.; Catella, F.; Entman, S.S.; FitzGerald, G.A. Increased thromboxane biosynthesis in normal pregnancy is mainly derived from platelets. Am. J. Obstet. Gynecol. 1987, 157, 325-330. [CrossRef]

53. Boilard, E.; Larabee, K.; Shnayder, R.; Jacobs, K.; Farndale, R.W.; Ware, J.; Lee, D.M. Platelets participate in synovitis via Cox-1-dependent synthesis of prostacyclin independently of microparticle generation. J. Immunol. 2011, 186, 4361-4366. [CrossRef] [PubMed]

54. Palmer, D.G.; Hogg, N.; Revell, P.A. Lymphocytes, polymorphonuclear leukocytes, macrophages and platelets in synovium involved by rheumatoid arthritis. A study with monoclonal antibodies. Pathology 1986, 18, 431-437. [CrossRef] [PubMed]

55. Konttinen, Y.T.; Bergroth, V.; Kulomaa, M.; Nordstrom, D.; Segerberg-Konttinen, M.; Keinanen, R.; Kemppinen, P.; Hukkanen, M.; Gronblad, M. Localisation of lysozyme mRNA in rheumatoid synovial membrane by in situ hybridisation. Ann. Rheum. Dis. 1989, 48, 912-917. [CrossRef] [PubMed]

56. Wang, F.; Wang, N.S.; Yan, C.G.; Li, J.H.; Tang, L.Q. The significance of platelet activation in rheumatoid arthritis. Clin. Rheumatol. 2007, 26, 768-771. [CrossRef] [PubMed]

57. Knijff-Dutmer, E.A.; Koerts, J.; Nieuwland, R.; Kalsbeek-Batenburg, E.M.; van de Laar, M.A. Elevated levels of platelet microparticles are associated with disease activity in rheumatoid arthritis. Arthritis Rheum. 2002, 46, 1498-1503. [CrossRef] [PubMed]

58. Bunescu, A.; Seideman, P.; Lenkei, R.; Levin, K.; Egberg, N. Enhanced Fcgamma receptor I, $\alpha \mathrm{M} \beta 2$ integrin receptor expression by monocytes and neutrophils in rheumatoid arthritis: Interaction with platelets. J. Rheumatol. 2004, 31, 2347-2355. [PubMed]

59. Gasparyan, A.Y.; Sandoo, A.; Stavropoulos-Kalinoglou, A.; Kitas, G.D. Mean platelet volume in patients with rheumatoid arthritis: The effect of anti-TNF- $\alpha$ therapy. Rheumatol. Int. 2010, 30, 1125-1129. [CrossRef] [PubMed]

60. Jurk, K.; Kehrel, B.E. Platelets: Physiology and biochemistry. Semin. Thromb. Hemost. 2005, 31, 381-392. [CrossRef] [PubMed]

61. Sellam, J.; Proulle, V.; Jungel, A.; Ittah, M.; Richard, C.M.; Gottenberg, J.E.; Toti, F.; Benessiano, J.; Gay, S.; Freyssinet, J.M.; et al. Increased levels of circulating microparticles in primary Sjogren's syndrome, systemic lupus erythematosus and rheumatoid arthritis and relation with disease activity. Arthritis Res. Ther. 2009, 11, R156. [CrossRef] [PubMed]

62. Goules, A.; Tzioufas, A.G.; Manousakis, M.N.; Kirou, K.A.; Crow, M.K.; Routsias, J.G. Elevated levels of soluble CD40 ligand (sCD40L) in serum of patients with systemic autoimmune diseases. J. Autoimmun. 2006, 26, 165-171. [CrossRef] [PubMed]

63. Pamuk, G.E.; Vural, O.; Turgut, B.; Demir, M.; Pamuk, O.N.; Cakir, N. Increased platelet activation markers in rheumatoid arthritis: Are they related with subclinical atherosclerosis? Platelets 2008, 19, 146-154. [CrossRef] [PubMed]

64. Joseph, J.E.; Harrison, P.; Mackie, I.J.; Isenberg, D.A.; Machin, S.J. Increased circulating platelet-leucocyte complexes and platelet activation in patients with antiphospholipid syndrome, systemic lupus erythematosus and rheumatoid arthritis. Br. J. Haematol. 2001, 115, 451-459. [CrossRef] [PubMed]

65. Endresen, G.K. Investigation of blood platelets in synovial fluid from patients with rheumatoid arthritis. Scand. J. Rheumatol. 1981, 10, 204-208. [CrossRef] [PubMed]

66. Endresen, G.K.; Forre, O. Human platelets in synovial fluid. A focus on the effects of growth factors on the inflammatory responses in rheumatoid arthritis. Clin. Exp. Rheumatol. 1992, 10, 181-187. [PubMed]

67. Yaron, M.; Djaldetti, M. Platelets in synovial fluid. Arthritis Rheum. 1978, 21, 607-608. [CrossRef] [PubMed]

68. Farr, M.; Wainwright, A.; Salmon, M.; Hollywell, C.A.; Bacon, P.A. Platelets in the synovial fluid of patients with rheumatoid arthritis. Rheumatol. Int. 1984, 4, 13-17. [CrossRef] [PubMed]

69. Ginsberg, M.H.; Breth, G.; Skosey, J.L. Platelets in the synovial space. Arthritis Rheum. 1978, 21, $994-995$. [CrossRef] [PubMed]

70. Boilard, E.; Nigrovic, P.A.; Larabee, K.; Watts, G.F.; Coblyn, J.S.; Weinblatt, M.E.; Massarotti, E.M.; Remold-O'Donnell, E.; Farndale, R.W.; Ware, J.; et al. Platelets amplify inflammation in arthritis via collagen-dependent microparticle production. Science 2010, 327, 580-583. [CrossRef] [PubMed]

71. Riddle, J.M.; Bluhm, G.B.; Pitchford, W.C.; McElroy, H.; Jimenea, C.; Leisen, J.; Venkatasubramanian, K. A comparative study of platelet reactivity in arthritis. Ann. N. Y. Acad. Sci. 1981, 370, 22-29. [CrossRef] [PubMed] 
72. Mullan, P.A.M.; Peace, A.J.; Madigan, A.M.; Tedesco, A.F.; Kenny, D.; McCarthy, G.M. Platelet hyper-reactivity in active inflammatory arthritis is unique to the adenosine diphosphate pathway: A novel finding and potential therapeutic target. Rheumatology 2010, 49, 240-245. [CrossRef] [PubMed]

73. Garcia, A.E.; Mada, S.R.; Rico, M.C.; Cadena, R.A.D.; Kunapuli, S.P. Clopidogrel, a P2Y12 receptor antagonist, potentiates the inflammatory response in a rat model of peptidoglycan polysaccharide-induced arthritis. PLoS ONE 2011, 6, e26035. [CrossRef] [PubMed]

74. Kawashiri, S.Y.; Taguchi, M.; Kawakami, A.; Eguchi, K. Clopidogrel-associated acute arthritis. Rheumatol. Int. 2012, 32, 449-450. [CrossRef] [PubMed]

75. Garg, A.; Radvan, J.; Hopkinson, N. Clopidogrel associated with acute arthritis. BMJ 2000, $320,483$. [PubMed]

76. Kanadiya, M.K.; Singhal, S.; Koshal, V.B. Prasugrel as a safe alternative for clopidogrel-associated arthritis. J. Invasive Cardiol. 2011, 23, E137-E138. [PubMed]

77. Tayyareci, Y. Acute arthritis associated with loading dose of clopidogrel. J. Clin. Rheumatol. 2008, 14, $254-255$. [CrossRef] [PubMed]

78. Chen, K.K.; Ginges, I.; Manolios, N. Clopidogrel-associated acute arthritis. Intern. Med. J. 2003, 33, 618-619. [CrossRef] [PubMed]

79. Boulman, N.; Rozenbaum, M.; Slobodin, G.; Rosner, I. Acute polyarthritis associated with clopidogrel treatment. Israel Med. Assoc. J. 2005, 7, 670-671.

80. Forrest, C.M.; Stone, T.W.; Mackay, G.M.; Oxford, L.; Stoy, N.; Harman, G.; Darlington, L.G. Purine metabolism and clinical status of patients with rheumatoid arthritis treated with dipyridamole. Nucleosides Nucleotides Nucleic Acids 2006, 25, 1287-1290. [CrossRef] [PubMed]

81. Vowinkel, T.; Anthoni, C.; Wood, K.C.; Stokes, K.Y.; Russell, J.; Gray, L.; Bharwani, S.; Senninger, N.; Alexander, J.S.; Krieglstein, C.F.; et al. CD40-CD40 ligand mediates the recruitment of leukocytes and platelets in the inflamed murine colon. Gastroenterology 2007, 132, 955-965. [CrossRef] [PubMed]

82. Mori, M.; Stokes, K.Y.; Vowinkel, T.; Watanabe, N.; Elrod, J.W.; Harris, N.R.; Lefer, D.J.; Hibi, T.; Granger, D.N. Colonic blood flow responses in experimental colitis: Time course and underlying mechanisms. Am. J. Physiol. Gastrointest. Liver Physiol. 2005, 289, G1024-G1029. [CrossRef] [PubMed]

83. Gironella, M.; Molla, M.; Salas, A.; Soriano, A.; Sans, M.; Closa, D.; Engel, P.; Salas, A.; Pique, J.M.; Panes, J. The role of P-selectin in experimental colitis as determined by antibody immunoblockade and genetically deficient mice. J. Leukocyte Biol. 2002, 72, 56-64. [PubMed]

84. Nunez-Andrade, N.; Lamana, A.; Sancho, D.; Gisbert, J.P.; Gonzalez-Amaro, R.; Sanchez-Madrid, F.; Urzainqui, A. P-selectin glycoprotein ligand-1 modulates immune inflammatory responses in the enteric lamina propria. J. Pathol. 2011, 224, 212-221. [CrossRef] [PubMed]

85. Brown, J.B.; Cheresh, P.; Zhang, Z.; Ryu, H.; Managlia, E.; Barrett, T.A. P-selectin glycoprotein ligand-1 is needed for sequential recruitment of T-helper 1 (Th1) and local generation of Th17 T cells in dextran sodium sulfate (DSS) colitis. Inflamm. Bowel Dis. 2012, 18, 323-332. [CrossRef] [PubMed]

86. Rijcken, E.M.; Laukoetter, M.G.; Anthoni, C.; Meier, S.; Mennigen, R.; Spiegel, H.U.; Bruewer, M.; Senninger, N.; Vestweber, D.; Krieglstein, C.F. Immunoblockade of PSGL-1 attenuates established experimental murine colitis by reduction of leukocyte rolling. Am. J. Physiol. Gastrointest. Liver Physiol. 2004, 287, G115-G124. [CrossRef] [PubMed]

87. Yoshida, H.; Granger, D.N. Inflammatory bowel disease: A paradigm for the link between coagulation and inflammation. Inflamm. Bowel Dis. 2009, 15, 1245-1255. [CrossRef] [PubMed]

88. Voudoukis, E.; Karmiris, K.; Koutroubakis, I.E. Multipotent role of platelets in inflammatory bowel diseases: A clinical approach. World J. Gastroenterol. 2014, 20, 3180-3190. [CrossRef] [PubMed]

89. Harries, A.D.; Fitzsimons, E.; Fifield, R.; Dew, M.J.; Rhoades, J. Platelet count: A simple measure of activity in Crohn's disease. Br. Med. J. 1983, 286, 1476. [CrossRef]

90. Harries, A.D.; Beeching, N.J.; Rogerson, S.J.; Nye, F.J. The platelet count as a simple measure to distinguish inflammatory bowel disease from infective diarrhoea. J. Infect. 1991, 22, 247-250. [CrossRef]

91. Larsen, T.B.; Nielsen, J.N.; Fredholm, L.; Lund, E.D.; Brandslund, I.; Munkholm, P.; Hey, H. Platelets and anticoagulant capacity in patients with inflammatory bowel disease. Pathophysiol. Haemost. Thromb. 2002, 32, 92-96. [CrossRef] [PubMed]

92. Morowitz, D.A.; Allen, L.W.; Kirsner, J.B. Thrombocytosis in chronic inflammatory bowel disease. Ann. Intern. Med. 1968, 68, 1013-1021. [CrossRef] [PubMed] 
93. Collins, C.E.; Rampton, D.S. Platelet dysfunction: A new dimension in inflammatory bowel disease. Gut 1995, 36, 5-8. [CrossRef] [PubMed]

94. Collins, C.E.; Cahill, M.R.; Newland, A.C.; Rampton, D.S. Platelets circulate in an activated state in inflammatory bowel disease. Gastroenterology 1994, 106, 840-845. [CrossRef]

95. Collins, C.E.; Rampton, D.S. Review article: Platelets in inflammatory bowel disease-Pathogenetic role and therapeutic implications. Aliment. Pharmacol. Ther. 1997, 11, 237-247. [CrossRef] [PubMed]

96. Danese, S.; Katz, J.A.; Saibeni, S.; Papa, A.; Gasbarrini, A.; Vecchi, M.; Fiocchi, C. Activated platelets are the source of elevated levels of soluble CD40 ligand in the circulation of inflammatory bowel disease patients. Gut 2003, 52, 1435-1441. [CrossRef] [PubMed]

97. Irving, P.M.; Macey, M.G.; Shah, U.; Webb, L.; Langmead, L.; Rampton, D.S. Formation of platelet-leukocyte aggregates in inflammatory bowel disease. Inflamm. Bowel Dis. 2004, 10, 361-372. [CrossRef] [PubMed]

98. Patel, S.H.; Rachchh, M.A.; Jadav, P.D. Evaluation of anti-inflammatory effect of anti-platelet agent-clopidogrel in experimentally induced inflammatory bowel disease. Indian J. Pharmacol. 2012, 44, 744-748. [PubMed]

99. Kohnke, T.; Gomolka, B.; Bilal, S.; Zhou, X.; Sun, Y.; Rothe, M.; Baumgart, D.C.; Weylandt, K.H. Acetylsalicylic Acid reduces the severity of dextran sodium sulfate-induced colitis and increases the formation of anti-inflammatory lipid mediators. BioMed Res. Int. 2013, 2013, 748160. [CrossRef] [PubMed]

100. Langer, H.F.; Haubner, R.; Pichler, B.J.; Gawaz, M. Radionuclide imaging: A molecular key to the atherosclerotic plaque. J. Am. Coll. Cardiol. 2008, 52, 1-12. [CrossRef] [PubMed]

101. Steinman, L. Platelets provide a bounty of potential targets for therapy in multiple sclerosis. Circ. Res. 2012, 110, 1157-1158. [CrossRef] [PubMed]

102. Schleicher, R.I.; Reichenbach, F.; Kraft, P.; Kumar, A.; Lescan, M.; Todt, F.; Gobel, K.; Hilgendorf, I.; Geisler, T.; Bauer, A.; et al. Platelets induce apoptosis via membrane-bound FasL. Blood 2015, 126, 1483-1493. [CrossRef] [PubMed]

(C) 2016 by the authors; licensee MDPI, Basel, Switzerland. This article is an open access article distributed under the terms and conditions of the Creative Commons Attribution (CC-BY) license (http://creativecommons.org/licenses/by/4.0/). 